\title{
Changing Microbiological Pattern of Pediatric Febrile Neutropenia
}

\author{
Anirban Mandal ${ }^{1 *}$ and Amitabh Singh ${ }^{2}$ \\ Department of Pediatrics, Sitaram Bhartia Institute of Science and Research, New Delhi, India \\ Department of Pediatrics, Chacha Nehru Bal Chikitsalaya, New Delhi, India
}

*Corresponding author: Dr. Anirban Mandal, Department of Pediatrics, Sitaram Bhartia Institute of Science and Research, B-16 Qutub Institutional Area, New Delhi, India, Tel: +918826836670; E-mail: anirban.nrs@gmail.com

Received date: September 27, 2016; Accepted date: October 17, 2016; Published date: October 21, 2016

Copyright: (c) 2016 Anirban M, et al. This is an open-access article distributed under the terms of the Creative Commons Attribution License, which permits unrestricted use, distribution, and reproduction in any medium, provided the original author and source are credited.

Keywords: Antibiotic resistance; Coagulase negative Staphylococcus aureus, Infection control

\section{Introduction}

Febrile Neutropenia (FN) is undoubtedly the commonest emergency in children with malignancy, especially those receiving chemotherapy. Even in this 'era of antibiotics' FN continues to be one of the major cause of morbidity and mortality in children with cancer; limiting the gains achieved with the chemotherapeutic agents [1]. Febrile neutropenia is defined as a single oral temperature of $>38.3^{\circ} \mathrm{C}$ $\left(101^{\circ} \mathrm{F}\right)$ or a temperature of $>38^{\circ} \mathrm{C}\left(100.4^{\circ} \mathrm{F}\right)$ for more than 1 hour with an absolute neutrophil count (ANC) $<500 / \mathrm{mm}^{3}$ or an ANC that is expected to decrease to $<500 / \mathrm{mm}^{3}$ during the next $48 \mathrm{hrs}$ [2]. The risk of infection is related to the duration and severity of neutropenia. The prevalence varies widely and estimated to be $12.8 \%$ in children between 1- 9 yrs but increases to $17.4 \%$ in those aged $10-19$ yrs [3].

Attributes that guides the management considerations in FN include: (1) fever in a neutropenia child is considered to be due to infection unless proved otherwise; (2) microbiological diagnosis is possible in only about $10-30 \%$ cases of pediatric FN [4]; Organisms with low virulence or those considered as potential contaminants in an immunocompetent patient can lead to serious infection in presence of neutropenia; $(3,4)$ co-infection with multiple organisms are common and untreated infection can rapidly disseminate and lead to fatality. Among the infectious causes of FN in children, bacteria outnumber other agents (viral, fungal and parasitic); discussion in this paper will be limited to microbiology of bacterial agents in FN only. During the 1960s and 1970s, mortality from FN was in the tunes of $60-70 \%$ [5]. Subsequently, empirical use of antibiotics in FN demonstrated $[6,7]$ a striking reduction in the mortality. This paved the way for the present practice of empirical broad spectrum antibiotics in this group of patients. Clinicians further realized that all the children with neutropenia and fever were not at a same risk of having an invasive bacterial infection. The host vulnerability to infection and related complications depends on the patients' underlying disease and the chemotherapy they receive [5]. Indeed an audit of all hospital admission for pediatric FN during the year 2012 in US [8] revealed that $39 \%$ of the discharges had a short length of stay (SLOS) of $\leq 3$ days; viral infection and upper respiratory infection comprising the majority with $66.4 \%$ of them had no identifiable infections. This has led to the risk based approach and use of intravenous or oral antibiotics in 'low risk' patients [9]. Another important paradigm in the management of pediatric $\mathrm{FN}$ is use of antibiotic prophylaxis. Primary prophylaxis for $P$. jirovecii pneumonia has decreased associated morbidity and mortality in children with FN [10]. Trimethoprim/sulfamethoxazole, amoxicillin/clavulanate and fluoroquinolones have been used as antibacterial prophylaxis in these children with success, but has been linked with the risk of emergence of antibiotic resistance [1]. Past several decades have witnessed substantial change in the bacterial etiology of pediatric febrile neutropenia (Table 1).

\begin{tabular}{|c|c|c|c|c|}
\hline Author & Country & Study period & Predominant organisms & Antibiotic sensitivity pattern \\
\hline al-Fawaz IM et al. [11] & Saudi Arabia & $1983-89$ & 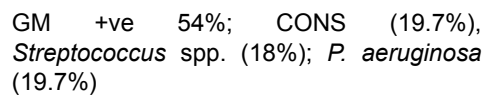 & NA \\
\hline Bakshi et al. [12] & India & $1992-2002$ & $\begin{array}{l}\text { GM -ve }(67 \%) ; \text { E. coli }(45.7 \%) \text {, S. aureus } \\
(39 \%)\end{array}$ & NA \\
\hline Celkan et al. [13] & Turkey & $1995-2001$ & GM +ve (60\%); CONS (40\%) & $\begin{array}{l}\text { High rates of resistance to penicillin, } \\
\text { erythromycin and cephalosporins in } \\
\text { Staphyloccus }\end{array}$ \\
\hline Dubey et al. [14] & India & 1998-99 & $\begin{array}{l}\text { GM -ve }(83 \%) ; \text { Klebsiella }(46 \%) \text {, E. coli } \\
(27 \%)\end{array}$ & $\begin{array}{l}\text { Fifty percent of both Klebsiella and E. coli } \\
\text { were resistant to both cefotaxime and } \\
\text { amikacin }\end{array}$ \\
\hline Lai et al. [15] & Taiwan & 1999 & & \\
\hline El-Mahallawy et al. [16] & Egypt & 1999 & $\begin{array}{l}\text { GM +ve }(51.2 \%) \text {; polymicrobial }(13.7 \%) ; \\
\text { CONS }(16.2 \%) \text {, S. aureus }(13.4 \%)\end{array}$ & $\begin{array}{l}\text { Forty isolated organisms were resistant to all } \\
\text { used antibiotics }\end{array}$ \\
\hline Gupta et al. [17] & El Salvador & 2001 & $\begin{array}{l}\text { GM +ve (61\%); polymicrobial ( } 43 \%) \text {; CONS } \\
(30.4 \%) \text {, pseudomonas }(17.4 \%)\end{array}$ & NA \\
\hline
\end{tabular}


Citation: Anirban M, Amit S (2016) Changing Microbiological Pattern of Pediatric Febrile Neutropenia. J Antimicrob Agents 2: 126. doi:

Page 2 of 4

\begin{tabular}{|c|c|c|c|c|}
\hline Duncan et al. [18] & England & 2001-02 & GM +ve (82\%); CONS (64.2\%) & $\begin{array}{l}\text { Resistance to gentamicin in } 15.8 \% \text { CONS } \\
\text { isolates }\end{array}$ \\
\hline Sanboonrat et al. [19] & Thailand & $2006-07$ & $\begin{array}{l}\text { GM -ve }(52 \%) \text {; A. baumannii }(16 \%), \text { E. coli } \\
(12 \%), \text { Klebsiella }(12 \%)\end{array}$ & NA \\
\hline Aslan et al. [20] & Turkey & $2007-10$ & $\begin{array}{l}\text { Gram +ve }(56.4 \%) \text {; CONS }(31.7 \%) \text {, MRSA } \\
(7.9 \%) \text {; E. coli }(5.7 \%)\end{array}$ & $\begin{array}{l}\text { Forty percent of the enterococcus species } \\
\text { vancomycin resistant; 50\% pseudomonas } \\
\text { resistant to meropenam }\end{array}$ \\
\hline Bothra et al. [21] & India & $2009-10$ & $\begin{array}{l}\text { GM -ve }(78.2 \%) \text {; E. coli }(29 \%) \text {, S. aureus } \\
(26 \%)\end{array}$ & $\begin{array}{l}\text { GM -ve mostly sensitive to carbapenems, } \\
\text { amikacin, netilmicin, cefoperazone-sulbactam } \\
\text { and piperacillin-tazobactam but resistant to } \\
\text { cefotaxime, ceftazidime and ciprofloxacin; } \\
\text { most GR +ve resistant to amoxicillin- } \\
\text { clavulanate, but sensitive to erythromycin, } \\
\text { amikacin, netilmicin and ciprofloxacin. }\end{array}$ \\
\hline Al-Mulla et al. [22] & Qatar & 2004-11 & GM +ve (55\%); CONS (40\%) & $\begin{array}{l}\text { All GM +ve susceptible to linezolid and } \\
\text { streptogramins; all K. pneumoniae susceptible } \\
\text { to imipenem, meropenem, and amikacin; P. } \\
\text { aeruginosa } 100 \% \text { susceptible to all } \\
\text { antipseudomonal antibiotics }\end{array}$ \\
\hline Miedema et al. [23] & Netherlands & 2004-11 & $\begin{array}{l}\text { GM +ve (73\%); } \quad \text { CONS } \quad(39 \%), \\
\text { streptococcus }(26 \%)\end{array}$ & $\begin{array}{l}\text { All GM +ve susceptible to vancomycin; CONS } \\
\text { often resistant to penicillin, flucloxacillin, } \\
\text { gentamicin; GM -ve highly susceptible } \\
\text { toceftazidime, piperacillin/tazobactam, } \\
\text { imipenem, and aminoglycosides }\end{array}$ \\
\hline El-Mahallawy et al. [24] & Egypt & 2011 & GM +ve (72.4\%); CONS (58\%) & $51 \%$ isolated strains multidrug resistant \\
\hline Rose et al. [25] & India & 2012-14 & $\begin{array}{l}\text { GM -ve }(82.6 \%) ; \text { klebsiella }(12.8 \%) ; \text { CONS } \\
(31.4 \%)\end{array}$ & $\begin{array}{l}\text { Among GM -ve } 24 \% \text { carbapenem-resistant } \\
\text { and } 49 \% \text { ESBL; Among GM +ve } 33 \% \text { VRE } \\
\text { and } 15 \% \text { MRSA }\end{array}$ \\
\hline Siddaiahgari et al. [26] & India & 2013 & $\begin{array}{l}\text { GM -ve }(85.4 \%) ; \\
\text { pseudomonas }(23.5 \%)\end{array}$ & $\begin{array}{l}\text { GM -ve ESBL, carbepenem resistance and } \\
\text { pan resistance in } 31.4 \%, 5.6 \% \text { and } 2.3 \% \\
\text { respectively }\end{array}$ \\
\hline Hagag et al. [27] & Egypt & $2012-15$ & $\begin{array}{l}\text { GM -ve }(55.5 \%) \text {; pseudomonas }(31.5 \%) \\
\text { S. aureus }(25.9 \%)\end{array}$ & $\begin{array}{l}\text { GM -ve } 40 \% \text { resistant to ceftazidime } 36.6 \% \text { to } \\
\text { cefoperazone and } 13.3 \% \text { to imipenam; GM } \\
\text { +ve } 50 \% \text { resistant to oxacillin, } 37.5 \% \text { to } \\
\text { imipenam and } 12.5 \% \text { to cefepime }\end{array}$ \\
\hline
\end{tabular}

Table 1: Large epidemiological studies on pediatric febrile neutropenia, GM -ve=Gram negative; GM +ve =Gram positive; $C O N S=$ coagulase negative staphylococci; MRSA=Methicillin resistant Staphylococcus aureus; VRE=Vancomycin resistantenterococcus; ESBL=extended spectrum $\beta$-lactamase.

Apart from the time period of study, the microbiology of febrile neutropenia is largely dependent on the regional differences based on socio-economic and healthcare developments [11-27]. Data from European Organization for Research and Treatment of Cancer (EORTC) during 1973-1994, reveals a decreasing incidence of Gram negative agents from $71 \%$ to $31 \%$ while Gram positive infection rose from $29 \%$ to $69 \%$ [28]. A 15 yrs (1995-2010) data from Turkey on children with acute lymphoblastic leukemia (ALL) and FN showed an increasing incidence of febrile neutropenia during this period. Gram positive and Gram negative organisms were equally frequent with CONS and E. coli being the being the commonest Gram positive and Gram negative organisms respectively [29]. Till the 1990s the predominant etiological organism of pediatric FN world over were Gram positive bacteria but during the first decade of the 21st century Gram positive organisms became more prevalent specially in the developing countries with CONS (coagulase negative Staphyloccus aureus) being the most frequently isolated agent. Again during the present decade there seems to be a re-emergence of Gram negative organisms, particularly multidrug resistant (MDR) [11-27]. The same has been echoed in the study by Mikulska et al. [30], who found that a questionnaire based data obtained in 2011 reported predominance of Gram negative organisms compared to the published data between 2005-2011. It is also worth mentioning that the studies from developing countries such as India [12-14,21-26] have consistently demonstrated a predominance of Gram negative organisms, probably because of less use of central venous catheters. It is not only the predominant organism but their antibiotic sensitivity pattern that decide the choice of empirical antimicrobial therapy in children with FN.

Infection with antibiotic-resistant bacteria has emerged as a serious threat to children with fever and neutropenia. Mikulska et al. [30] in their review of studies between 2005 and 2011 revealed very high rates of antimicrobial resistance. In a retrospective review of all cases of Gram negative bacteraemia in children with febrile neutropenia from 2003-2010 at the Royal Children's Hospital Melbourne [31], revealed that $15 \%$ episodes were due to antibiotic resistant (AR) organisms. Factors independently associated with AR GN bacteremia were highintensity chemotherapy, hospital-acquired bacteremia and isolation of 
Page 3 of 4

AR GN bacteria from any site within the preceding 12 months. Though, episodes of AR GN bacteremia were associated with longer hospital stay including longer intensive care unit length of stay and a higher rate of invasive ventilation, no increase in mortality was identified. Another study reported 38\% isolates to be multidrug resistant and it was also associated with unfavorable outcome [32]. Risk factors for infection with such organisms were found to be hospitalization, Gram-negative organisms, presence of clinical focus of infection, reduced ANC, prolonged duration of neutropenia, and previous intake of antibiotics. Antibiotic susceptibility data of Gram negative isolates from children with FN between 2001 and 2013 at a single centre in Italy [33] revealed out of total 263 strains evaluated $27 \%$ were resistant to piperacillin-tazobactam, $23 \%$ to ceftazidime, $12 \%$ to meropenem and $13 \%$ to amikacin. Concomitant resistance to $\beta$ lactam and amikacin was detected in $6 \%$ of strains for piperacillintazobactam, 5\% for ceftazidime and 5\% for meropenem. During the study period there was a nonsignifcant increase in the proportions of strains resistant to $\beta$-lactams indicated for monotherapy, and also increase in the resistance to combined therapies. El-Mahallawy et al. [34] have documented a substantial rise in the multidrug resistant organisms between 2006 and 2011 (38\% vs. 51\%) at a single centre in Egypt. In a more recent study from Korea [35], 34.4\% episodes of febrile neutropenia were found to be due to ESBL producing strains of $E$. coli and $K$. pneumoniae. Again, there were no increased complications including mortality rates compared to non-ESBL producing organisms. It was also observed that $90.5 \%$ of the ESBLproducing isolates were susceptible to piperacillin/tazobactam or cefepime in combination with aminoglycoside. Therefore, authors concluded that empirical therapy with these combinations might be more useful for febrile neutropenic children, instead of $\beta$-lactam monotherapy in places with high prevalence of ESBL-producing organisms. Another alarming report from India [36] revealed 59\% of Gram negative isolates to be ESBL producing; multidrug resistance was seen in $48 \%$, extreme drug resistance in $32 \%$ and pan drug resistance in $16 \%$ of Gram negative isolates. Colistin was the most sensitive antibiotic ( $75 \%$ sensitivity) and in significant number of cases the only salvage option. A recent systematic review of randomized control trials in pediatric FN [37] concluded that antipseudomonal penicillin and fourth-generation cephalosporin monotherapy were associated with similar failure and mortality rates as aminoglycoside containing combination therapy. The current recommendations also advise monotherapy as initial empirical antibiotic therapy in pediatric FN [3-9]. Further, Outpatient management and oral antibiotics were found to be safe in low-risk FN with no infection-related mortality observed in any patient and no significant differences in outcomes compared with inpatient management and intravenous therapy. But the authors have rightly appreciated that combination empirical antibiotic therapy will be appropriate in settings with high rates of gram-negative antibiotic resistance. They further added that, a consensus regarding the minimum level of bacterial resistance for adopting combination therapy will be difficult as it will require individual institutions to balance the risk and theoretical benefits as well as their individual preferences. Nevertheless, it is incumbent on the institutions to offer strategies to monitor, prevent, and appropriately manage these infections. Simultaneously, there is need to address the current infection control issues pertaining to the children with haematological malignancy based on currently available recommendations [38].

\section{References}

1. Sung L, Phillips R, Lehrnbecher T (2011) Time for paediatric febrile neutropenia guidelines-children are not little adults. Eur J Cancer 47: 811-813.

2. Freifeld AG, Bow EJ, Sepkowitz KA, Boeckh MJ, Ito JI, et al. (2011) Infectious Diseases Society of America. Clinical practice guideline for the use of antimicrobial agents in neutropenic patients with cancer: 2010 Update by the Infectious Diseases Society of America. Clin Infect Dis 52: 427-431.

3. Mendes AV, Sapolnik R, Mendonça N (2007) New guidelines for the clinical management of febrile neutropenia and sepsis in pediatric oncology patients. J Pediatr 83: 54-63.

4. Meckler G, Lindemulder S (2009) Fever and neutropenia in pediatric patients with cancer. Emerg Med Clin N Am 27: 525-544.

5. Hakim H, Gaur AH (2011) Initial Management of Fever and Neutropenia in a Child with Cancer-The Past, the Present, and the Future. Clinical Pediatric Emergency Medicine 11: 174-184.

6. Schimpff S, Satterlee W, Young VM, Serpick A (1971) Empiric therapy with carbenicillin and gentamicin for febrile patients with cancer and granulocytopenia. N Engl J Med 284: 1061-1065.

7. Pizzo PA, Robichaud KJ, Gill FA, Witebsky FG (1982) Empiric antibiotic and antifungal therapy for cancer patients with prolonged fever and granulocytopenia. Am J Med 72: 101-111.

8. Mueller EL, Croop J, Carroll AE (2016) Fever and neutropenia hospital discharges in children with cancer: A 2012 update. Pediatr Hematol Oncol 33: 39-48.

9. Lehrnbecher T, Phillips R, Alexander S, Alvaro F, Carlesse F, et al. (2012) International Pediatric Fever and Neutropenia Guideline Panel. Guideline for the management of fever and neutropenia in children with cancer and/or undergoing hematopoietic stem-cell transplantation. J Clin Oncol 30: $4427-4438$.

10. Lindemulder S, Albano E (2007) Successful intermittent prophylaxis with trimethoprim/sulfamethoxazole 2 days per week for Pneumocystis carinii (jiroveci) pneumonia in pediatric oncology patients. Pediatrics 120: 47-51.

11. al-Fawaz IM, Kambal AM, al-Rabeeah AA, al-Rasheed SA, al-Eissa YA, et al. (1991) Septicaemia in febrile neutropenic children with cancer in Saudi Arabia. J Hosp Infect 18: 307-312.

12. Bakhshi S, Padmanjali KS, Arya LS (2008). Infections in childhood acute lymphoblastic leukemia: an analysis of 222 febrile neutropenic episodes. Pediatr Hematol Oncol 25: 385-392.

13. Celkan T, Ozkan A, Apak H, Diren S, Can G, et al (2002). Bacteremia in childhood cancer. J Trop Pediatr 48: 373-377.

14. Dubey AP, Singhal D, Prakash SK (2002). Febrile episodes in childhood malignancies. Indian Pediatr 39: 952-957.

15. Lai HP, Hsueh PR, Chen YC, Lee PI, Lu CY, et al. (2003) Bacteremia in hematological and oncological children with febrile neutropenia: experience in a tertiary medical center in Taiwan. J Microbiol Immunol Infect 36: 197-202.

16. El-Mahallawy H, Sidhom I, El-Din NH, Zamzam M, El-Lamie MM (2005) Clinical and microbiologic determinants of serious bloodstream infections in Egyptian pediatric cancer patients: a one-year study. Int J Infect Dis 9: 43-51.

17. Gupta S, Bonilla M, Gamero M, Fuentes SL, Caniza M, et al. (2011) Microbiology and mortality of pediatric febrile neutropenia in El Salvador J Pediatr Hematol Oncol 33: 276-280.

18. Duncan C, Chisholm JC, Freeman S, Riley U, Sharland M, et al (2007) A prospective study of admissions for febrile neutropenia in secondary paediatric units in South East England. Pediatr Blood Cancer 49: 678-681.

19. Sanboonrat P, Chainansamit S, Sriraksa K (2009) Febrile neutropenia in children with acute leukemia. Khon Kaen Medical Journal 33: 2-8.

20. Aslan S, Citak EC, Yis R, Degirmenci S, Arman D (2012). Bacterial spectrum and antimicrobial susceptibility pattern of bloodstream 
Citation: Anirban M, Amit S (2016) Changing Microbiological Pattern of Pediatric Febrile Neutropenia. J Antimicrob Agents 2: 126. doi: 10.4172/2472-1212.1000126

Page 4 of 4

infections in children with febrile neutropenia: experience of single center in southeast of Turkey. Indian J Microbiol 52: 203-208.

21. Bothra M, Seth R, Kapil A, Dwivedi SN, Bhatnagar S, et al. (2013) Evaluation of predictors of adverse outcome in febrile neutropenic episodes in pediatric oncology patients. Indian J Pediatr 80: 297-302.

22. Al-Mulla NA, Taj-Aldeen SJ, El Shafie S, Janahi M, Al-Nasser AA, et al. (2014) Bacterial bloodstream infections and antimicrobial susceptibility pattern in pediatric hematology/oncology patients after anticancer chemotherapy. Infect Drug Resist 7: 289-299.

23. Miedema KG, Winter RH, Ammann RA, Droz S, Spanjaard L, et al. (2013) Bacteria causing bacteremia in pediatric cancer patients presenting with febrile neutropenia-species distribution and susceptibility patterns. Support Care Cancer 21: 2417-2426.

24. El-Mahallawy HA, Hassan SS, El-Wakil M, Moneer MM, Shalaby L (2015) Increasing Antimicrobial Resistance Monitored in Surveillance Analysis of Blood Stream Infections in Febrile Neutropenic Pediatric Oncology Patients. Asian Pac J Cancer Prev 16: 5691-5695.

25. Rose W, Veeraraghavan B, George B (2015) Bloodstream infections in children with febrile neutropenia: Isolates and their antimicrobial susceptibility profle. Indian J Cancer 52: 495-496.

26. Siddaiahgari S, Manikyam A, Kumar KA, Rauthan A, Ayyar R (2014) Spectrum of systemic bacterial infections during febrile neutropenia in pediatric oncology patients in tertiary care pediatric center. Indian J Cancer 51: 403-405

27. Hagag AA, Hassan SM, Elgamasy MA, Afifi IK (2016) Study of Common Bacterial and Fungal Pathogens in Children with Hematological Malignancies during Febrile Neutropenia: Single Center Egyptian Study Infect Disord Drug Targets 16: 54-62.

28. Hughes WT, Armstrong D, Bodey GP (2002). 2002 guidelines for the use of antimicrobial agents in neutropenic patients with cancer. Clin Infect Dis 34: 730-751.

29. Özdemir N, Tüysüz G, Çelik N, Yantri L, Erginöz E, et al (2016) Febrile neutropenia in children with acute lymphoblastic leukemia: single center experience. Turk Pediatri Ars 51: 79-86.

30. Mikulska M, Viscoli C, Orasch C, Livermore DM, Averbuch D, et al Fourth European Conference on Infections in Leukemia Group (ECIL-4), a joint venture of EBMT, EORTC, ICHS, ELN and ESGICH/ESCMID (2014) Aetiology and resistance in bacteraemias among adult and paediatric haematology and cancer patients. J Infect 68: 321-331.

31. Haeusler GM, Mechinaud F, Daley AJ, Starr M, Shann F, et al. (2013) Antibiotic-resistant Gram-negative bacteremia in pediatric oncology patients-risk factors and outcomes. Pediatr Infect Dis J 32: 723-726.

32. El-Mahallawy HA, El-Wakil M, Moneer MM, Shalaby L (2011) Antibiotic resistance is associated with longer bacteremic episodes and worse outcome in febrile neutropenic children with cancer. Pediatr Blood Cancer 57: 283-288.

33. Castagnola E, Caviglia I, Pescetto L, Bagnasco F, Haupt R, et al. (2015) Antibiotic susceptibility of Gram-negatives isolated from bacteremia in children with cancer. Implications for empirical therapy of febrile neutropenia. Future Microbiol 10: 357-364.

34. El-Mahallawy HA, Hassan SS, El-Wakil M, Moneer MM, Shalaby L (2015) Increasing Antimicrobial Resistance Monitored in Surveillance Analysis of Blood Stream Infections in Febrile Neutropenic Pediatric Oncology Patients. Asian Pac J Cancer Prev 16: 5691-5695.

35. Han SB, Jung SW, Bae EY, Lee JW, Lee DG, et al. (2015) Extendedspectrum $\beta$-lactamaseproducing Escherichia coli and Klebsiella pneumoniae bacteremia in febrile neutropenic children. Microb Drug Resist 21: 244-2451.

36. Reddy R, Pathania S, Kapil A, Bakhshi S (2014) Review of spectrum and sensitivity of bacterial bloodstream isolates in children with malignancy: A retrospective analysis from a single center. Indian J Cancer 51: 425-427.

37. Robinson PD, Lehrnbecher T, Phillips R, Dupuis LL, Sung L (2016) Strategies for Empiric Management of Pediatric Fever and Neutropenia in Patients With Cancer and Hematopoietic Stem-Cell Transplantation Recipients: A Systematic Review of Randomized Trials. J Clin Oncol 34: 2054-2060.

38. Ruhnke M, Arnold R, Gastmeier P (2014) Infection control issues in patients with haematological malignancies in the era of multidrugresistant bacteria. Lancet Oncol 15: 606-619. 